\title{
Research on the Objective of Entrepreneurship Legal Education in Universities of Science and Technology
}

\author{
Hong-Zhen LIN \\ School of Management, Wuhan University of Science and Technology Wuhan, China \\ Distinct addresses: 947 He Ping Street, Hubei Wuhan 430081, China \\ linjingziran@126.com
}

\section{Key words: Entrepreneurship; Legal Education; Diversification Goal}

\begin{abstract}
The purpose of this paper is to research the objective of University Entrepreneurship legal education. Using the method of questionnaires and interviews, document study deeply, correctly understand and analyze the problem. Aim of College Students legal education is to improve the entrepreneurial legal knowledge level and to analyze and forecast the business legal risk. Effective measures and suggestion to reasonably set goals should be put forward based on the analysis of the problems existing in Universities of science and technology. The conclusion is the establishment of diversified and hierarchical entrepreneurial legal teaching goal, improving the University Entrepreneurship entrepreneurial law education system, establishing a professional law teachers and promote the entrepreneurial mode of legal education to improve entrepreneurial security on the target.
\end{abstract}

\section{Introduction}

The Ministry of Education issued "the ordinary undergraduate school of entrepreneurship education teaching basic requirements (Trial)", requires all colleges and universities for all students entrepreneurship courses, to enable students to master business knowledge, familiar with the business process, the solution of business laws and regulations, promote students' all-round development and employment. University Entrepreneurship legal education is an important part of University Entrepreneurship education. China's entrepreneurial law education solves the need for a large number of entrepreneurial competency law, economic management of high technology talents. Education should adapt to the era of knowledge economy transformation and meeting the need for high-quality creative talents. This is closely related to the establishment of legal education in Colleges and universities as the provider of legal education. The cultivation of College Students' awareness of legal risk prevention of innovation and entrepreneurship is of great significance to the success of innovation and entrepreneurship. There are many problems in the cultivation of awareness in the current university student innovative legal awareness of risk prevention work of teaching, training methods and teaching content. These need to change for further reform of the existing legal education ideas, perfecting the education system of legal risk prevention, and integration of resources to build innovation and entrepreneurship student legal services platform [1]. Entrepreneurship education is a complicated system engineering, and rule of law society, entrepreneurship education in Colleges and universities must pay attention to the entrepreneurial law education, improve the teaching system, help students establish entrepreneurial legal literacy and legal awareness, to enable students to pursue their own economic interests, legal risk prevention within the scope of the law, to achieve sustainable development. In developed countries, entrepreneurship education began to rise in 1960s, and there have been relatively perfect legal and institutional guarantees [2].

Science and engineering students, relying on advanced professional skills, should be the main force of College Students' entrepreneurship, and have inherent advantages of entrepreneurship. However, because of professional characteristics of engineering, lack less of law capacity, engineering students do not make the most of professional knowledge to achieve entrepreneurial dreams. Legal knowledge become their entrepreneurial short board. In order to solve the dilemma 
of entrepreneurial law education for engineering college students, we need to further strengthen the law philosophy, improve the law knowledge system and build the practice platform, so as to realize the science and Engineering College Students' innovative talents training the target.

\section{Establishing the Basic Principles of Entrepreneurship Legal Education Goals}

\section{First, Adhering to the Problem Oriented, Paying Attention to Legal Risk Education.}

Under the new standard of public entrepreneurship and innovation, college students' enthusiasm for innovation and entrepreneurship has become a university culture. However, there are many problems such as the diversity of entrepreneurial mentality and the weak risk awareness of college students, which puts forward higher requirements for entrepreneurship education in Colleges and universities. Entrepreneurship education institutions of the university itself are not perfect and the lack of qualified teachers. Therefore, Colleges and universities should pay attention to improve the organizational structure and the practice of entrepreneurship education platform, innovation and entrepreneurship education training programs and teachers, strengthen the practical and specific laws of entrepreneurship education [3]. In order to solve the existing problems of innovation and entrepreneurship education in Colleges and universities as a focal point to deepen the innovation of education reform, integrating the personnel training system, enriching the curriculum, teaching innovation, strengthening teachers, helping to improve closely, promoting the teaching and scientific research, practicing, training the weak link of breakthrough talent, is helpful to enhance students' innovative spirit and entrepreneurial consciousness and innovation ability and improve legal awareness and take precautions against venture capital as the dominant factor.

\section{Second, Developing the Ability to Guard against Law Risks.}

To study legal education objectives, demand analysis is the starting point. Schools should regard the needs of students as the center. Demand analysis includes two aspects: the demand for the improvement of university students' legal quality and the demand of entrepreneurship for law. In the new normal Chinese economy into innovation driven development, public entrepreneurship, innovation, accelerate the "Internet plus" new industry put forward new requirements emerge in an endless stream, the times of people's innovation ability, innovation spirit and innovation consciousness, thinking and thinking habits [4].

It is the teaching goal of law education for non-Law Majors in the science and engineering colleges to take the businessman as the center and train the businessmen with legal awareness. The construction of the curriculum system around the needs of the businessmen should be the characteristic of the legal education of the schools [5].

\section{Third, Improving the Law Professional Competence.}

College students should do a good job of knowledge reserve in the university stage, and lay the foundation for stepping into the society. The employment of university students in China the main destination for venture enterprises, legal education content and the enterprise is closely related to the knowledge of enterprise legal for graduates to solve legal problems encountered in the work and to become qualified builders. From this point of view, entrepreneurship legal education belongs to pre service education, and should focus on training students' ability to use, so as to improve their law professional competence. As the basic elements of the legal quality of College Students' quality structure, legal knowledge belongs to the essential part of College Students' knowledge structure.

At the same time, Suitable education is not an education of individualism. Although it does not reject the individual interests of students, it does not advocate selfishness, and does not regard the individual interests of students as the only value choice. Suitable education stresses that every student is the growth of the individual communication in specific class, class, grade, school and community activities. Through active dialogue the proper education is based on the collective, in order to achieve through collective education. In such educational activities, each student individual is no longer independent. School leadership management is a specialized work. As the professional 
staff who fulfill the responsibilities of school leadership and management, it is necessary for school principals to change their concept of leadership management in time and give full play to the role of leadership and management. Only in this way, suitable education may fall to the ground and leap into the school's daily education and teaching practice [6].

\section{Problems of Entrepreneurship Legal Education}

\section{Firstly, no Definite Teaching Objectives.}

There are some problems that cannot be ignored in practice. Some local colleges and universities is seriously insufficient, lag concept innovation and entrepreneurship education and professional education. Teachers lack awareness and ability, teaching methods single, pertinence is not strong in the practice of carrying out innovation and entrepreneurship education. Practice platform shortage guidance is not in place, the entrepreneurship education system innovation to be perfect.

Some domestic ordinary university curriculum design reference domestic universities mostly focus on foreign university courses, involving enterprise establishment, financing, marketing, management and other aspects, mainly including "entrepreneurial base", "entrepreneurial opportunity recognition" and "leadership" course. The design and development of the management of education curriculum in our universities is in initial stage and a fragmented state. The entrepreneurship courses lack of penetration among different disciplines, the combination of basic and practical courses, and a small number of courses are rare.

\section{Secondly, Lack of Systematization.}

In the legal teaching of College Students' entrepreneurship, it is found that the legal curriculum has been marginalized in the entrepreneurship education of college students and has not yet formed a complete curriculum system, which cannot meet the educational objectives required by the Ministry of education. There is a serious deviation in the course content. Because the legal knowledge involved in enterprises is too complicated, how to select the content of teaching becomes a difficult problem in the legal education of entrepreneurship. Teaching content is too numerous, that the student is incompetent. Entrepreneurship students face entrepreneurial organization internal and external legal risks. Students should master both legal knowledge, legal consciousness and the ability to solve legal problems. There are objective reasons. Therefore, the internal legal education should be strengthened and the legal knowledge access threshold system should be implemented [7].

\section{Effective Measures to Ensure the Legal Education Objectives of Entrepreneurship}

\section{Firstly, Setting Up the Reasonable Teaching Target of Entrepreneurship Law.}

At present, entrepreneurship education in China's colleges and universities is geared to all students, so that all students have a certain entrepreneurial awareness and entrepreneurial ability. However, the social needs and individual differences of students determine that it is impossible for every student to become an entrepreneur. Therefore, the goal of entrepreneurial law education should be divided into two levels: the first level is for all students through the course of entrepreneurial law education, the basic knowledge of business law, establishing the consciousness of legal risk prevention preliminary; the second level is for the business plan competition practice found that entrepreneurial intention or entrepreneurial qualities students, which lays a foundation of knowledge through entrepreneurial law courses through entrepreneurial legal practice. This classification is beneficial to meet the different needs of different students, and is also beneficial to the effective allocation of limited resources in schools.

Secondly, Developing Multi-Level, Three-Dimensional Entrepreneurial Law Curriculum System.

Courses are based on gradient development objectives to meet the needs of students. In the 
entrepreneurship education for college students in the teaching process, to enable students to understand the relevant laws and regulations of the enterprise, cultivate their legal awareness, improve their ability to deal with the legal risks, it is necessary to set up related law courses and gradually establish a risk prevention and control system, constructing entrepreneurship education of legal science [8].

The specific type of radiation is for all students undertaking the basic course of law if it is not a separate course, can be used as a basis for entrepreneurship curriculum teaching module. Students set up the risk prevention consciousness of micro business layer. The entrepreneurial intention of Students base on students' professional and industry background, where the provincial regional industrial planning and policy the national macro industrial planning and industrial policies. Some industrial policies are encouraged, but some are restricted and some are prohibited. Focusing with the professional development and the international industrial transfer and international trade and investment policy of the integration of entrepreneurial law courses, schools set up some elective courses. Elective students according to their own business needs select elective courses to guide students to rational Entrepreneurship, reasonable positioning.

\section{Thirdly, Compiling Legal Teaching Materials.}

According to students majoring schools should study the development of education materials for in science and engineering. The development of teaching materials is also divided into many levels. Entrepreneurial behavior is always in certain time and space conditions. Laws that need to be followed are national, local, and international conventions and international conventions that our country has concluded. school-based teaching materials should focusing on the development of school-based teaching materials, mainly based on schools in the region and the school's professional and professional background. This kind of teaching material can also be used in Universities of science and engineering with different types of professional background. The textbook is divided into 3 parts from the shallower to the deeper.

\section{Fourthly, Strengthening the Teachers' Teaching Ability.}

Colleges and universities should make clear the responsibility of all the teachers for innovation and entrepreneurship education, improving the standards of professional and technical posts evaluation and performance evaluation, and strengthening the assessment of innovation and entrepreneurship education. Teachers guide complete with strong innovation entrepreneurship education and employment, and establish a regular evaluation and elimination system. It is necessary to employ successful entrepreneurs, venture capitalists and other talents in all walks of life, as part-time teachers and developing standardized management. To improve the consciousness and ability of University Teachers' innovation and entrepreneurship education is an important content of pre job training. Good teachers and teaching methods are good for encouraging leading the students to innovation and entrepreneurship.

Entrepreneurial law education is of great significance to improve the students' legal literacy, promote college students' Entrepreneurship and employability, entrepreneurship curriculum should be based on the legal quality education both the cultivation of College Students' occupation competency [9].

\section{Conclusion}

Our national development and national rejuvenation need a large number of innovative talents with innovative spirit, innovative consciousness and creative ability. To deepen the innovation and entrepreneurship education reform as a breakthrough to promote the comprehensive reform, higher education should set up the advanced concept of innovation and entrepreneurship education. Classification of teaching with professional practice promote all-round development of students, improving the quality of human capital to make new entrepreneurship innovation mass. Therefore, we should attach importance to the cultivation of College Students' legal quality, lay a solid foundation for the cultivation of innovative talents in higher education. We should take the 
cultivation of innovative talents as the basic social responsibility of their own, deepening the reform of talent cultivating pattern to meet diverse development needs of the real effective support in the process of legal education. We should go through a period of unremitting efforts to transform our legal education into the cradle of entrepreneurial talents.

\section{Acknowledgement}

This research was financially supported by Project research of The National Education Science "13th Five-Year" plan of the 2017 National Social Science Project: " entrepreneurial law education research based on risk control in science and Engineering University ", No. BIA170192

\section{References}

[1] Huang Yankui. Problems and Countermeasures for the Training of Legal Risk Prevention Awareness for College Students' Innovation and Entrepreneurship [J]. Legal System and Economy, 2017 (4): 17-19

[2] Xie Fang. Entrepreneurship Education Need To Focus On Training The Consciousness Of The Rule Of Law [J]. Realism, 16 (8): 71-72.

[3] Wu Yize. Study on the Problems and Countermeasures of Entrepreneurship Education in Colleges and Universities under the New Normal [J]. Ideological Education 2016 (2): 100-103.

[4], Chen Guoliang, Zhang Ye, Li Weitao. Facing the Future Science Planning, Education Modernization [N] China Education Daily, June 8, 2017,

[5], Zhu Zhuo. Study On The Construction Of Curriculum System Based On The Policy Of Small And Medium Micro Enterprises And The Legal Needs Of Higher Vocational Students [J]. Science and Technology Innovation Guide, 2016 (13): 158-159.

[6], Zhang Xinping. What is meant of proper education?" [N]China Education Daily, 2017, 05, 10.

[7] Lin Qiao. Legal risk and prevention mechanism of college students [J]. Education and profession, 2016, 1 (11):75-77.

[8], Huang Jialin, Liao Ruibin. Discussion on the Construction of Legal Curriculum System for College Students' Entrepreneurship Education [J]. Law and economics, 2015 (z2): 29-30.

[9] Dong Xinhong. Enterprise Legal Courses of College Students [J]. Heilongjiang higher education research, 2015 (7): 111-113. 